\title{
Evaluation of Piper guineense in the Control of Cowpea Storage Weevils: Implication for Sustainable Credit Advancement
}

\author{
Gabriel Adedotun Sunday Benson' ${ }^{1}$, Abiodun Oladipupo Joda², Olufemi Sunday Sosanya², \\ Babajimi Olumide Tokoya ${ }^{3}$
}

${ }^{1}$ School of Agriculture, Lagos State Polytechnic, Ikorodu, Nigeria

${ }^{2}$ Olabisi Onabanjo University, Ago-Iwoye, Nigeria

${ }^{3}$ Central Bank of Nigeria, Abuja, Nigeria

Email: gasbenson@yahoo.com

How to cite this paper: Benson, G.A.S., Joda, A.O., Sosanya, O.S. and Tokoya, B.O. (2019) Evaluation of Piper guineense in the Control of Cowpea Storage Weevils: Implication for Sustainable Credit Advancement. Agricultural Sciences, 10, 530-537. https://doi.org/10.4236/as.2019.104042

Received: December 24, 2018

Accepted: April 21, 2019

Published: April 24, 2019

Copyright $\odot 2019$ by author(s) and Scientific Research Publishing Inc. This work is licensed under the Creative Commons Attribution International License (CC BY 4.0).

http://creativecommons.org/licenses/by/4.0/

\section{(c) (i) Open Access}

\begin{abstract}
The Central Bank of Nigeria Anchored Borrowers Programme efforts geared towards massive production of cowpea and sustainable food security is challenged with post-harvest losses especially due to insect pest infestation in storage. So also, chemical method of pest control posed more health and ecological challenges than food insecurity. This work investigated the effect of Piper guineense on cowpea storage weevil at the agronomy laboratory of the Lagos State Polytechnic, Ikorodu. Contact toxicity of $P$. guineense at $0.2,0.4,0.6,0.8$ and $1 \mathrm{~g}$ per $20 \mathrm{~g}$ of cowpea seeds in test tubes including a control was observed. The treatment materials exhibited significant efficacy from 24 hours after infestation. P. guineense at $1 \mathrm{~g}$ concentration significantly reduced the oviposition potential, egg hatching rate, holes and emergence of adult Callosobruchus maculatus on treated seeds. The powders caused chronic toxicity and inhibit development. All the responses were found to be concentration dependent. Increasing rates of $P$. guineense increased performance. The implication of these results is discussed and recommendations proffered.
\end{abstract}

\section{Keywords}

Concentration, Cowpea, Efficacy, Storage Weevil, Piper guineense

\section{Introduction}

Cowpea (Vigna unguiculata L. Walp) is a pulse crop that is grown successfully in extreme environments such as high temperatures, low rainfall and poor soils with few inputs. Cowpea grain is important to the incomes of resource-poor 
farmers as well as to the nutritional status and diets of people in West Africa [1]. The seed is high in protein contents and can be consumed directly, make flour, weaning foods for young children and thus ameliorating malnourishment, wasting and stunting. It also provides a useful complement in diets comprised mainly of roots, tubers or cereals. The Central Bank of Nigeria Anchored Borrowers Programme which is basically for small holder farmers is perceived to be successful based on its achievements in disbursement and utilization of fund by over four hundred thousand $(400,000)$ farmers across the country [2] and the accompanying massive production of cowpea which is still far below storage capacity especially in the northern part of the country. Post-harvest losses of cowpea grain are also a serious problem in Africa. Storage insect pest infestation results in seed weight loss and quality deterioration. The most important is the cowpea storage weevil Callosobruchus maculatus Fabr [3]. Heat, moisture and waste products produced by the weevil also result in further deterioration and the growth of moulds with adverse antecedent effect on market prices. This renders cowpea grain unfit for consumption and selling. Thus, farmers are forced to sell their products early after harvest when prices are still low partly because of anticipated losses in storage due to the pest. These pests have often been controlled with synthetic pesticides not easily available to poor resource farmers, and when available, are too expensive [4]. So also, the ecological implication of the use of these chemical materials is of great concern to environmentalist. As such, farmers have reverted to the usage of natural products that include plant extracts in the control of pests with varying levels of effectiveness. So, the impulse of the success so recorded by the CBN programme will not be fully felt if adequate protective measures are not put in place. Thus, the use of natural plant products, which are cheap, effective and less toxic to mammals, easy to adopt and environmentally friendly, has been investigated worldwide [3] [5] [6] [7] [8] [9]. In Nigeria, indigenous plant materials such as Neem (Azadirachta indica), Bush pepper (Piper guineense), Scent leaf (Ocimum viridis) have been used in different capacities as pesticides [10]. $P$. guineense is used as anti convulsant; extract of $P$. guineense has been reported to enhance digestion of food by stimulating secretion of digestive enzymes [11]. Olotuah et al. [12] reported the efficacy of $P$. guineense dust at different particle size in the control of Callosobruchus maculatus. Thus, more investigations are necessary to explore natural protectants that abound in large numbers in the country.

This study was therefore conducted to evaluate the efficacy of contact toxicity of different levels of $P$. guineense powder in controlling cowpea storage weevil with a view to commercializing the product.

\section{Materials and Methods}

The experiment was conducted at the Agronomy Laboratory of Crop Production Department, School of Agriculture, Lagos State Polytechnic, Ikorodu, The area lies between Latitude $5^{\circ} 10^{\prime}$ North and Longitude $3^{\circ} 16^{\prime}$ East of the Greenwich 
Meridan. It has an altitude of $50 \mathrm{~m}$ above the sea level with a mean average temperature between $25^{\circ} \mathrm{C}$ and $29^{\circ} \mathrm{C}$ and $74 \%$ relative humidity from December to February when this work was carried out.

C. maculates used for the study was derived from colony originating from infested cowpea seeds obtained from Sabo Market, Ikorodu. The emerged adults were sub-cultured in the laboratory $\left(28^{\circ} \mathrm{C} \pm 3^{\circ} \mathrm{C}, 70 \% \pm 5 \% \mathrm{R}\right.$. H) till new insects emerge. The seeds of cowpea used as bioassay were properly sieved and handpicked to ensure that only whole and uninfected seeds were used. Dry fruits of $P$. guineense also purchased from the same market were grinded into $150 \mu \mathrm{m}$ and kept in an air tight container. The powder of $P$. guineense was tested at $0.2,0.4$, $0.6,0.8$ and $1.0 \mathrm{~g}$ per $20 \mathrm{~g}$ of cowpea in test tubes. Each of the test tubes was tumbled several times to ensure homogeneous mixing of powder with grains. Three pairs of $C$. maculatus were introduced into each test tube. Adult mortality was monitored and counted from 1, 3, 5, 7, 12 hours, 1, 2, 3, 4 and 5 days after infestation (DAI) using Henderson-Tilton formula:

$$
\% \text { efficacy }=\left(1-\frac{\mathrm{Ta}}{\mathrm{Ca}} \times \frac{\mathrm{Cb}}{\mathrm{Tb}}\right) \times 100
$$

where $\mathrm{Tb}=$ infestation in treated plot before application,

$\mathrm{Ta}=$ infestation in treated plot after application,

$\mathrm{Cb}=$ infestation in the check plot before application,

$\mathrm{Ca}=$ infestation in the check plot after application.

And thereafter, all insects were removed 1weeks later. The numbers of eggs laid were counted and adult emergence was checked from 21 days after withdrawal.

Data collection:

1) Adult mortality was recorded at 1, 3, 5, 7, $12 \mathrm{hrs}, 1,2,3,4$ and 5 DAI by counting.

2) Percent efficacy was calculated using the Henderson-Tilton formula.

3) Egg oviposition was recorded by counting the number of eggs laid on seeds.

4) Adult emergence was by counting number of newly emerged insects 21 days after withdrawal of initial insects.

5) Number of holes on cowpea seeds was also counted.

6) Grain loss in weight was taken with the use of a digital weighing scale model SF-400.

Experimental design and data analysis:

The experimental design used for the experiment was Completely Randomized Design (CRD) and each treatment was replicated three times. Egg counts were subjected to square root transformation; percentage adult mortality and emergence were arc sine transformed and efficacy determined using the Henderson Tilton method. Data collected was subjected to analysis of variance (ANOVA), using SPSS software package. Treatment means were separated using Turkey test at $\mathrm{P}<0.05$. 


\section{Results}

The effects of $P$. guineense on oviposition, adult emergence, number of holes, weight loss and mortality of $C$. maculates is as obtained in Table 1 . No mortality was recorded at $1,3,5,7,12$ and 12 hours after application. There was significant difference $(\mathrm{P}<0.05)$ in adult mortality from different levels of $P$. guineense dust compared with the control.

At 1DAI, the highest mortality was recorded on cowpea seeds treated with 0.8 and $0.6 \mathrm{~g}$ piper, significantly different from other treatment. The lowest mortality was recorded from treatment with $0.4 \mathrm{~g}$ piper. At $2 \mathrm{DAI}$, the highest kill was observed from treatment with $0.8 \mathrm{~g} / 20 \mathrm{~g}$ seed not significantly different from other insecticide treatments. No mortality was recorded from the control. At 3DAI, $0.8 \mathrm{~g}$ piper $/ 20 \mathrm{~g}$ gave the best performance not significantly different from 0.6 and $0.4 \mathrm{~g}$ but significantly better than treatments with $0.2 \mathrm{~g}$ and the control, other insecticide treatments. At 4 and 5DAI, seeds treated with 1.0 g piper resulted in the highest insect mortality not significantly different from treatments with 0.8 and $0.6 \mathrm{~g}$ but significantly different from 0.4 and $0.2 \mathrm{~g}$ piper treatments. The control recorded a zero percent efficacy. Result from the table also shows that at 5DA all insecticide treatments were effective in the control of cowpea storage weevil haven achieved efficacy above $40 \%$. The best performance was from $1.0 \mathrm{~g}$ piper $/ 20 \mathrm{~g}$ seeds not significantly different from 0.8 and $0.6 \mathrm{~g}$ piper treatments. The result in the table also showed that the mean number of eggs laid by $C$. maculatus was significantly $(\mathrm{P}<0.05)$ higher on untreated cowpea seeds not significantly different from $0.6,0.4$, and $0.2 \mathrm{~g}$ piper treated seeds. The lowest number of eggs was recorded from $1.0 \mathrm{~g}$ piper treatment not significantly different from $0.8 \mathrm{~g} / 20 \mathrm{~g}$ seeds.

Result on adult emergence from cowpea seeds show that there were significant differences $(P<0.05)$ in weevil emergence among treatments. The highest number of adult emergence was observed on the control untreated seeds while the lowest was recorded from the $1.0 \mathrm{~g}$ piper/20 g seed. The general trend is a decrease in weevil emergence with increased piper application. The same trend of a decrease in holes with an increase in piper was observed. The control recorded significantly higher number of holes on the seeds while treatment with $1.0 \mathrm{~g} P$. guineense recorded the lowest number of holes closely followed by treatment with $0.8 \mathrm{~g}$ piper. Analysis of variance indicated that there were significant differences among the treatments. $P$. guineense applied at $0.2,0.4,0.6,0.8$ and 1.0 $\mathrm{g} / 20 \mathrm{~g}$ seed had a significantly $(\mathrm{P}<0.05)$, A reduced loss in grain weigh was observed in the insecticide treatments compared with the control.

Regressing increasing rates of $P$. guineense with egg oviposition, adult emergence, seed weight loss and adult mortality showed significant positive relationship (Table 2). Increasing the rate of application of the treatment material increased its efficiency in the control of the cowpea bruchid, increase in adult mortality and reduced seed weight loss. However, the cost implications of the 
Table 1. Effect of $P$. guineense on oviposition, adult emergence, number of holes, weight loss and mortality of $C$. maculatus.

\begin{tabular}{|c|c|c|c|c|c|c|c|c|c|c|}
\hline \multirow{2}{*}{ Treatments } & \multicolumn{5}{|c|}{ Insect mortality in days after infestation (DAI) } & \multirow{2}{*}{$\begin{array}{l}\text { Percent } \\
\text { efficacy }\end{array}$} & \multirow{2}{*}{$\begin{array}{c}\text { Egg } \\
\text { Oviposition }\end{array}$} & \multirow{2}{*}{$\begin{array}{c}\text { Adult } \\
\text { emergence }\end{array}$} & \multirow{2}{*}{$\begin{array}{c}\text { No. of } \\
\text { exit holes }\end{array}$} & \multirow{2}{*}{$\begin{array}{l}\text { Loss in seed } \\
\text { wt (g) }\end{array}$} \\
\hline & 1 & 2 & 3 & 4 & 5 & & & & & \\
\hline $0.2 \mathrm{~g} P$. guineense & $1.00^{\mathrm{ab}}$ & $2.00^{\mathrm{a}}$ & $2.33^{\mathrm{b}}$ & $3.33^{\mathrm{c}}$ & $4.67^{\mathrm{b}}$ & $55.50^{c}$ & $29.33^{\mathrm{ab}}$ & $21.33^{\mathrm{b}}$ & $19.77^{\mathrm{b}}$ & $1.7^{\mathrm{b}}$ \\
\hline $0.4 \mathrm{~g}$ P. guineense & $0.33^{\mathrm{b}}$ & $2.67^{\mathrm{a}}$ & $3.00^{\mathrm{ab}}$ & $4.33^{\mathrm{bc}}$ & $5.33^{\mathrm{ab}}$ & $72.17^{\mathrm{b}}$ & $28.00^{\mathrm{ab}}$ & $20.00^{\mathrm{bc}}$ & $19.00^{\mathrm{bc}}$ & $1.3^{\mathrm{bc}}$ \\
\hline $0.6 \mathrm{~g}$ P. guineense & $2.00^{\mathrm{a}}$ & $3.00^{\mathrm{a}}$ & $4.00^{\mathrm{ab}}$ & $5.00^{\mathrm{ab}}$ & $5.67^{\mathrm{ab}}$ & $83.33^{\mathrm{ab}}$ & $25.77^{\mathrm{ab}}$ & $19.66^{\mathrm{bc}}$ & $18.77^{\mathrm{bc}}$ & $1.0^{\mathrm{bc}}$ \\
\hline $0.8 \mathrm{~g}$ P. guineense & $2.00^{\mathrm{a}}$ & $3.33^{\mathrm{a}}$ & $4.33^{\mathrm{a}}$ & $5.33^{\mathrm{ab}}$ & $5.67^{\mathrm{ab}}$ & $88.83^{\mathrm{ab}}$ & $23.77^{b c}$ & $16.77^{\mathrm{c}}$ & $16.00^{c}$ & $0.3^{\text {cd }}$ \\
\hline $1.0 \mathrm{~g}$ P. guineense & $0.77^{\mathrm{b}}$ & $2.67^{\mathrm{a}}$ & $3.67^{\mathrm{ab}}$ & $6.00^{\mathrm{a}}$ & $6.00^{\mathrm{a}}$ & $100.00^{\mathrm{a}}$ & $21.77^{\mathrm{cd}}$ & $16.77^{\mathrm{c}}$ & $6.00^{\mathrm{d}}$ & $0.0^{\mathrm{d}}$ \\
\hline Control & $0.00^{\mathrm{b}}$ & $0.00^{\mathrm{b}}$ & $0.00^{c}$ & $0.00^{\mathrm{d}}$ & $1.00^{c}$ & $0.00^{\mathrm{d}}$ & $32.00^{\mathrm{a}}$ & $24.00^{\mathrm{a}}$ & $23.33^{\mathrm{a}}$ & $2.7^{\mathrm{a}}$ \\
\hline
\end{tabular}

Means followed by the same letters are not significantly different at $5 \%$ probability level.

Table 2. Simple correlation and regression between increasing rate of $P$. guineense and oviposition, adult emergence, number of holes, seed weight loss and mortality of $C$. maculates at 5 days after infestation $(\mathrm{n}=5)$.

\begin{tabular}{cccc}
\hline Parameters & Correlation coefficient $(\mathrm{r})$ & Regression equation & Significant level \\
\hline Oviposition & 0.78 & $\mathrm{Y}=31.567+1.438 \mathrm{X}$ & $* *$ \\
Adult emergence & 0.72 & $\mathrm{Y}=22.667+1.109 \mathrm{X}$ & $*$ \\
Number of holes on seed & 0.73 & $\mathrm{Y}=20.967+0.884 \mathrm{X}$ & $*$ \\
Seed weight loss & 0.99 & $\mathrm{Y}=2.157+0.064 \mathrm{X}$ & (*** \\
Adult mortality & 0.83 & $\mathrm{Y}=1.933+0.245 \mathrm{X}$ & $* * *$ \\
Percent efficacy & 0.86 & $\mathrm{Y}=29.000+3.509 \mathrm{X}$ & $* * *$ \\
\hline
\end{tabular}

${ }^{\star} \mathrm{P} \leq 0.1 ;{ }^{* *} \mathrm{P} \leq 0.05 ;{ }^{* * *} \mathrm{P} \leq 0.01 ;{ }^{* * *} \mathrm{P} \leq 0.001$.

increase in application rates were not put into consideration in this instance. It may be necessary to factor in the cost in relation to the increase in rate to know the profitability of the different rates.

\section{Discussion}

This study shows that $1.0 \mathrm{~g}$ piper/20 g seed is most effective killing significantly more weevils, reducing grain damage and loss in weight than other concentrations. The performance of $P$. guineense in this work might be due to piperine, piperidine and chavicine constituents in it. Okonkwo and Okoye [13] had earlier reported that $P$. guineense contains piperine and chavicine which are insecticidal. The family piperaceae to which $P$. guineense belongs has also been reported to possess some forms of insecticidal properties which are capable of suppressing various developmental instars of C. maculates [14]. Ofuya [15], Ofuya and Dawodu [16], Asawalam and Emosairue [17], Asawalam et al. [18], Kabeh and Jalingo [19] have previously reported that $P$. guineense powder has a significant contact toxicity action against stored product insect pests. They further postulated that the powder may also cause physical abrasion to the cuticle of bruchids with a resultant loss of body fluids or blockage of spiracles. The ability of the plant powders to significantly cause adults mortality of $C$. maculatus, inhibiting 
oviposition and eventual suppression of $F_{1}$ progeny emergence can be attributed to contact toxicity of the powders.

So also, the performance of the insecticide powders $(150 \mu \mathrm{m})$ used in this work is supported by the findings of Fasakin and Aberego [20] who reported that pulverized plant material from $P$. guineense inhibited egg hatchability, adult emergence of Dermestes maculatus in smoked catfish (Clarias gariepinus) during storage. Similar effects of plant materials as insect protectants have also been observed in the treatment of cowpea and maize weevils [16] [21]. Application of $P$. guineense significantly inhibited egg laying by the female beetles compared to control. The reduction in eggs laid and adult emergence of $C$. maculatus from cowpea seeds treated with $P$. guineense powder compared with the control suggested that $C$. maculatus development was adversely affected by the different levels of $150 \mu \mathrm{m} P$. guineense particle size. This is in agreement with the findings of Asawalam and Emosairue [17], and Asawalam et al. [18] who reported the efficacy of pepper Piper guineense powder and pirimiphos methyl dust against $\mathrm{Si}$ tophilus zeamais. The observed efficacy of $P$. guineense powder on increased adult mortality, oviposition inhibition and suppression of $\mathrm{F}_{1}$ progeny emergence are all concentration dependent. This is in line with the previously reported work by Golob et al. [5] and Waqar et al. [6].

\section{Conclusion}

It is concluded that an effective control of cowpea weevil is achievable with the application of $P$. guineense and therefore recommended for further adoption. The profitability of the different rates of the tested material is suggested for further investigation. Based on the results achieved, the government is implored to put in place policy geared towards those measures that will ensure that as funds are advanced to the poor resource farmers, their knowledge and efficiency in the use of plant-derived protectants are broadened to produce an all-year-round good quality food while the health of the producer and the environment are not jeopardized. Such measures should also include the identification of more potential plant materials with insecticidal properties to control pests. These will ultimately ensure success in government programme towards self-sufficiency of quality foodstuff.

\section{Conflicts of Interest}

The authors declare no conflicts of interest regarding the publication of this paper.

\section{References}

[1] Langyintuo, A.S., Lowenberg, J., Faye, M., Lambert, D., Ibro, G. and Moussa, B., (2003) Cowpea Supply and Demand in West and Central Africa. Field Crops Research, 82, 215-231. https://doi.org/10.1016/S0378-4290(03)00039-X

[2] Oche, J.T. (2018) Nirsal, CBN and Anchor Borrowers Programme. 
https://www.sunnewsonline.com/nirsal-cbn-and-anchor-borrowers-programme/

[3] Oparaeke, A.M. and Daria, V.S. (2005) Toxicity of Some Plant Powders to Callosobruchus maculatus (Fab.) on Stored Cowpea. Nigeria Journal of Entomology, 22, 76-83.

[4] Umeozor, O.C. (2001) Piper guineense (Thonn.) as a Protectant of Melon (Citrulus vulgaris (Schard) against Merchant Beetle Oryzaephilus mercator (Fauvel) (Coleoptera: Silvanidae): A Laboratory Evaluation. Nigerian Journal of Entomology, 18, 88-94.

[5] Golob, P., Farrell, G. and John, E. (2008) Crop Post-Harvest: Science and Technology, Vol. 1: Principles and Practice. Wiley-Blackwell, Hoboken, NJ, 548.

[6] Islam, W., Rasool, A. and Wu, Z. (2016) Inhibitory Effects of Medicinal Plant Extracts against Tribolium castaneum (Herbst.) (Coleoptera: Tenebrionidae). Mayfeb Journal of Agricultural Science, 3, 15-20.

[7] Okonkwo, E.U. and Okoye, W.I. (2001) Insecticide Activity of Dennettia tripetala B and Piper guineense Schum and Thonn against Dermestes maculatus Degeer (Coleoptera: Dermastidae) and Necrobia rufipes Degeer (Coleoptera: Cleridae) on Dried Fish. Nigerian Journal of Entomology, 18, 109-117.

[8] Benson, G.A.S., Ofuya, T.I., Aladesanwa, R.D. and Okeowo, T.A. (2015) Biocide Application in Okra (Abelmoschus esculentus L. Moench) Production and Implications for Profitabilty in South Western Nigeria. International Journal of Applied research and Technology, 4, 3-9.

[9] Benson, G.A.S. (2017) Efficacy of Selected Synthetic Insecticides and Botanicals for the Control of Insect Pests on Okra (Abelmoschus esculentus L. Moench). International Journal of Forestry and Horticulture, 3, 1-5.

[10] Abila, B.A., Richens, J.A. and Davies, D.A. (1993) Anticonvulsant Effects of Extracts of the West African Black Pepper, Piper guineense. Journal of Ethnopharmacology, 39, 113-117.

[11] Platel, K. and Sinnivasan, K. (2000) Influence of Digestive Spices and Their Active Principles on Pancreatic Digestive Enzymes in Albino Rats. Nahrung, 44, 42-46. https://doi.org/10.1002/(SICI)1521-3803(20000101)44:1<42::AID-FOOD42>3.0.CO; $\underline{2-\mathrm{D}}$

[12] Olotuah, O.K., Ofuya, T.I. and Aladesanwa, R.D. (2007) Effect of Particle Size on Insecticidal Activity of Dust of Eugenia aromatica and Piper guineense against Callosobruchus maculatus. Nigeria Journal of Plant Protection, 24, 34-39.

[13] Okonkwo, E.U. and Okoye, W.I. (1996) The Efficacy of Four Seed Powders and Their Essential Oils as Protectants of Cowpea and Maize Grains against Infestation by Callosobruchus maculates (Fabricius) (Coleoptera: Bruchidae) and Sitophilus zeamais (Motschulsky) (Coleoptera: Curculionidae) in Nigeria. International Journal of Pest Management, 42, 143-146. https://doi.org/10.1080/09670879609371985

[14] Adedire, C.O. and Lajide, L. (1999) Toxicity and Oviposition Deterrence of Some Plants Extracts on Cowpea Storage Bruchid, Callosobruchus maculates Fabricius. Journal of Plant Diseases and Protection, 106, 647-653.

[15] Ofuya, T.I. (2001) Biology, Ecology and Control of Insect Pests of Stored Legumes in Nigeria. In: Ofuya, T.I. and Lale, N.E.S., Eds., Pests of Stored Cereals and Pulses in Nigeria, Dave Collins Publication, Nigeria, 24-58.

[16] Ofuya, T.I. and Dawodu, E.O. (2002) Aspects of Insecticidal Action of Piper guineense Schum and Thonn Fruit Powders against Callosobruchus maculatus (F.) (Coleoptera: Bruchidae). Nigerian Journal of Entomology, 19, 40-50. 
[17] Asawalam, E.F. and Emosairue, S.O. (2006) Comparative Efficacy of Pepper Piper guineense (Schum and Thonn) Powder and Pirimiphos methyl Dust against Sitophilus zeamais Motsch (Coleoptera: Curculionidae) in Stored Maize. Nigerian Journal of Entomology, 23, 30-33.

[18] Asawalam, E.F., Emosairue, S.O., Ekeleme, F. and Wokocha, R. (2007) Efficacy of Piper guineense (Schum and Thonn) Seed Extract against Maize Weevil Sitophilus zeamais (Motschulsky) as Influenced by Different Extraction Solvents. International Journal of Pest Management, 53, 1-6. https://doi.org/10.1080/09670870600968784

[19] Kabeh, J.D. and Jalingo, M.G.D.S. (2007) Pesticidal Effect of Bitter Leaf Plant Vernonia amygdalina (Compositae) Leaves and Pirimiphos methyl on Larvae of Callosobruchus maculatus (Coleoptera: Bruchidae) and Sitophilus zeamais (Coleoptera: Curculionidae). International Journal of Agriculture and Biology, 9, 452-454.

[20] Fasakin, E.A. and Aberejo, B.A. (2002) Effect of Some Pulverized Plant Materials on the Developmental Stages of Fish Beetle, Dermestes maculates Degeer in Smoked Catfish (Clarias gariepinus) during Storage. Bioresource Technology, 85, 173-177. https://doi.org/10.1016/S0960-8524(02)00058-5

[21] Adedire, C.O. and Ajayi, T.S. (1996) Assessment of the Insecticidal Properties of Some Plant Extracts as Grain Protectant against the Maize Weevil S. zeamais Motschulsky. Nigerian Journal of Entomology, 13, 93-101. 